\title{
Uji Aktivitas Antibakteri Ekstrak Etanol Daun Yen Thuo (Leea indica Merr.) Terhadap Bakteri Staphylococcus epidermidis Serta Pembuatan Sediaan Krimnya
}

\author{
Muharti Sanjaya \\ Dosen Prodi Farmasi Fakultas Kesehatan Universitas Efarina (koresponden)
}

\begin{abstract}
ABSTRAK
Daun yen thuo (Leea indica Merr.) merupakan tanaman yang digunakan sebagai obat tradisional yang dapat membantu mengobati berbagai macam penyakit kanker dan juga sebagai antiseptik. Di Kabupaten Karo daun yen thuo digunakan sebagai ramuan tradisional yang dicampurkan dengan samsu putih sebagai obat anti tetanus dan infeksi luka. Di Malaysia, daun yen thuo juga digunakan sebagai obat infeksi luka dan buahnya digunakan untuk proses memercepat pematangan buah (memeram). Tujuan penelitian ini adalah untuk mengetahui golongan kandungan senyawa kimia, uji aktivitas antibakteri ekstrak etanol daun yen thuo terhadap bakteri Staphylococcus epidermidis serta formulasi sediaan krimnya.Serbuk simplisia diskrining fitokimia kemudian diekstraksi secara maserasi menggunakan pelarut etanol $70 \%$ sehingga diperoleh ekstrak kental, selanjutnya dilakukan uji aktivitas antibakteri ekstrak etanol terhadap bakteri Staphylococcus epidermidis yang dilakukan dengan metode difusi agar menggunakan pencadang kertas. Setelah didapat diameter hambatan yang efektif, ekstrak etanol daun yen thuo kemudian diformulasikan dengan sediaan dasar krim.Hasil skrining fitokimia simplisia daun yen thuo menunjukkan adanya golongan senyawa alkaloida, flavonoida, tanin, saponin, steroid/triterpenoid dan glikosida. Hasil uji aktivitas antibakteri menunjukkan bahwa ekstrak etanol daun yen thuo memiliki aktivitas yang efektif sebagai antibakteri pada konsentrasi $100 \mathrm{mg} / \mathrm{ml}$ terhadap bakteri Staphylococcus epidermidis dengan diameter daerah hambat rata-rata $15,33 \mathrm{~mm}$.
\end{abstract}

Kata kunci: daun yen thuo; Staphylococcus epidermidis; krim antibakteri

\section{PENDAHULUAN}

Tumbuhan yen thuo dipercaya dapat mengobati berbagai macam penyakit kanker. Juga dapat membantu mengobati cedera/ luka pada kulit dengan cara mengoleskan cairan dari daun yang sudah dihaluskan pada kulit yang cedera. Masyarakat di Kabupaten Karo menggunakan ramuan daun ini sebagai obat antitetanus dan obat infeksi luka. Di Kelantan - Malaysia, tumbuhan ini digunakan untuk mempercepat proses pematangan buah (peram/ memeram).

Cedera atau luka adalah suatu kerusakan pada struktur atau fungsi tubuh karena suatu paksaan atau tekanan fisik maupun kimiawi. Seperti luka bakar, luka gores/ sayat, patah tulang, memar, lecet serta luka pada kulit yang dapat mengakibatkan pendarahan. Apabila luka dibiarkan saja tanpa pengobatan, maka lama kelamaan dapat mempersilahkan masuk berbagai macam virus dan bakteri yang dapat menyebabkan infeksi. Infeksi biasanya disebabkan oleh beberapa mikroorganisme seperti bakteri, parasit, virus dan jamur. Bakteri yang sering menimbulkan infeksi pada manusia adalah Staphylococcus epidermidis, Pseudomonas aeruginosa, dan Klebsiella pneumonia (Jawetz, et al., 2005). Bakteri Staphylococcus epidermidis adalah flora normal pada kulit dan diisolasi dari darah yang terkontaminasi (Motoyama, dkk., 2009).

Infeksi adalah proses masuknya parasit dan mengadakan hubungan dengan inang. Infeksi terjadi apabila parasit itu sanggup mengadakan penetrasi atau melalui pertahanan inang dan hidup didalamnya (Irianto, 2006). Infeksi juga merupakan penyebab utama penyakit di dunia, terutama di daerah tropis seperti Indonesia (Kuswandi, et al., 2001).

Pengobatan infeksi dengan kombinasi berbagai antibiotik yang semula dipercaya sebagai obat yang mampu memusnahkan bakteri penyebab infeksi ternyata juga menimbulkan permasalahan baru, yaitu munculnya bakteri yang multiresisten (Maryati, et al., 2007). Munculnya pertimbangan resistensi antibiotik merupakan pengurangan efikasi antibiotik yang serius dan dapat meningkatkan jumlah infeksi yang sulit untuk diobati. Pengembangan obat non-antibiotik mulai dikembangkan untuk mengatasi adanya suatu masalah resisten terhadap antibiotik (Chusri et al., 2009). Berdasarkan pengalaman masyarakat yang sudah merasakan khasiat dari tumbuhan ini, maka dilakukan penelitian uji aktivitas antibakteri dari ekstrak etanol terhadap pertumbuhan bakteri Staphylococcus epidermidis serta pembuatan krimnya. 


\section{METODE}

Penelitian ini dilaksanakan di Laboratorium Mikrobiologi dan Laboratorium Formulasi Resep Universitas Efarina, Jl. Sudirman No.8 Pematang siantar, Kabupaten Simalungun, Sumatera Utara. Penelitian ini dilakukan dengan menggunakan metode eksperimental parametrik. Parameter yang digunakan mengacu pada Materia Medika Indonesia. Uji aktivitas antibakteri dilakukan dengan metode difusi agar menggunakan pencadang kertas. Parameter yang diukur adalah besarnya zona hambat disekitar pencadang kertas. Penelitian ini meliputi pengumpulan dan pengolahan sampel, pemeriksaan karakterisasi simplisia secara organoleptis, skrining fitokimia simplisia daun yen thuo, pembuatan ekstrak etanol daun yen thuo, uji aktivitas antibakteri ekstrak etanol daun yen thuo dan formulasi sediaan krim ekktrak etanol daun yen thuo. Pengujian aktivitas antibakteri terhadap bakteri Staphylococcus epidermidis. Alat-alat yang digunakan dalam penelitian ini adalah tangas air, cawan penguap, cawan petri, beaker glass, erlenmeyer, flakon, gelas ukur, batang pengaduk, blender, aluminium foil, cakram kertas, jarum ose, jarum suntik, spatula, pinset, mikropipet, wadah krim, mortar dan stamper, jangka sorong, kaca objek, mikroskop, lemari pendingin, kertas perkamen, sudip, neraca analitik dan tabung reaksi. Bahan-bahan yang digunakan untuk penelitian ini adalah daun yen thuo (Leea Indica Merr), serbuk dan ekstrak daun yen thuo (Leea Indica Merr), bakteri Staphylococcus epidermidis, air suling, etanol, nutrient agar (NA), $\mathrm{NaCl}$ 0,9\% (infus), mueller hinton agar (MHA), dimetilsulfoksida (DMSO), pereaksi Meyer, pereaksi Dragendorff, asam klorida pekat, besi (III) klorida, kloroform, natrium klorida, metanol, kloralhidrat, pereaksi Bouchardat, magnesium dan amil alkohol. Penyiapan sampel meliputi pengumpulan bahan tumbuhan dan pembuatan simplisia. Pengambilan bahan tumbuhan dilakukan secara purposif yaitu tanpa membandingkan tumbuhan yang sama dengan daerah lain. Bahan tumbuhan yang digunakan adalah bagian daun dari tumbuhan yen thuo. Bahan diambil dari lingkungan Puskesmas Batu Onom, Kabupaten Simalungun, Provinsi sumatera Utara.

Daun yen thuo dipilah terlebih dulu untuk memisahkan daun yang rusak (cacat atau dimakan ulat) dari daun yang akan digunakan. Daun kemudiaan dicuci bersih dari pengotoran dengan air mengalir sampai bersih dan ditiriskan. Kemudian dikeringkan dengan suhu sekitar $40^{\circ} \mathrm{C}$ dan tidak boleh terkena sinar matahari langsung. Daun yen thuo dianggap sudah kering apabila daun sudah menjadi rapuh (diremas akan bergemerisik dan menjadi hancur), kemudian simplisia daun yen thuo yang telah kering diserbuk dengan menggunakan blender. Serbuk simplisia dimasukkan ke dalam wadah plastik tertutup rapat. Serbuk simplisia disimpan pada suhu ruangan atau pada tempat yang kering, tidak lembab ataupun basah.

Karakterisasi simplisia dilakukan terhadap daun dan serbuk simplisia tumbuhan yen thuo dengan cara organoleptis mengamati bentuk, bau, rasa, warna dan ukuran simplisia serta secara mikroskopik mengamati serbuk simplisia dilakukan sebagai berikut. Sejumlah serbuk simplisia diletakkan merata diatas objek glass yang telah ditetesi larutan kloralhidrat, ditutupi dengan kaca penutup dan dilihat dibawah mikroskop.

Skrining fitokimia dari serbuk simplisia, ekstrak etanol, $n$-heksana dan etilasetat meliputi pemeriksaan golongan senyawa alkaloida, flavonoida, saponin, tanin, glikosida, glikosida antrakinon dan steroida/ triterpenoida (Depkes RI, 1995; Fransworth, 1996).

Serbuk simplisia ditimbang sebanyak $0,5 \mathrm{~g}$ kemudian ditambahkan $1 \mathrm{ml}$ asam klorida $2 \mathrm{~N}$ dan $9 \mathrm{ml}$ air suling, dipanaskan diatas penangas air selama 2 menit. Didinginkan dan disaring. Filtrat dipakai untuk percobaan sebagai berikut: Filtrat sebanyak 3 tetes ditambah dengan 2 tetes larutan pereaksi Meyer, akan terbentuk endapan menggumpal berwarna putih atau kuning. Fitrat sebanyak 3 tetes ditambah dengan 2 tetes larutan pereaksi Bouchardat, akan terbentuk endapan berwarna coklat sampai hitam. Filtrat sebanyak 3 tetes ditambah dengan 2 tetes larutan pereaksi Dragendorff, akan terbentuk endapan merah atau jingga.

Serbuk mengandung alkaloida jika sekurang- kurangnya terbentuk endapan dengan menggunakan dua golongan larutan percobaan yang digunakan (DepkesRI, 1995).

Pemeriksaan flavonoida sebanyak 0,5 g serbuk simplisia ditambahkan $20 \mathrm{ml}$ air panas, dididihkan selama 10 menit dan disaring dalam keadaan panas. Kedalam $5 \mathrm{ml}$ filtrat ditambahkan $0,1 \mathrm{~g}$ serbuk magnesium dan 1 $\mathrm{ml}$ asam klorida pekat dan $2 \mathrm{ml}$ amil alkohol, dikocok dan dibiarkan memisah. Flavonoida positif jika terjadi warna merah, kuning, jingga pada lapisan amil alkohol (Fransworth, 1966).

Pemeriksaan tannin sebanyak $0,5 \mathrm{~g}$ serbuk simplisia disari dengan $10 \mathrm{ml}$ air suling lalu disaring. Filtratnya diencerkan dengan air suling sampai menjadi bening (tidak berwarna). Larutan diambil sebanyak $2 \mathrm{ml}$ dan ditambahkan 1 sampai 2 tetes pereaksi besi (III) klorida $1 \%$. Jika terjadi warna hijau, biru, atau kehitaman menunjukkan adanya tanin (Fransworth, 1996).

Pemeriksaan saponin sebanyak $0,5 \mathrm{~g}$ serbuk simplisia dimasukkan kedalam tabung reaksi, ditambahkan $10 \mathrm{ml}$ air panas, didinginkan kemudian dikocok selama 10 detik. Jika terbentuk busa setinggi 1 sampai $10 \mathrm{~cm}$ yang stabil tidak kurang dari 10 menit dan tidak hilang dengan penambahan 1 tetes asam klorida $2 \mathrm{~N}$ menunjukkan adanya saponin (Depkes RI, 1995). 
Pemeriksaan steroid/triterpenoid sebanyak $1 \mathrm{~g}$ serbuk simplisia dimaserasi dengan $20 \mathrm{ml} n$-heksan selama 2 jam, lalu disaring. Filtrat diuapkan dalam cawan penguap. Sisa ditambahkan 20 tetes asam asetat anhidrida dan 1 tetes asam sulfat pekat(pereaksi Liebermann Burchard), diteteskan pada saat akan mereaksikan sampel uji.Timbulnya warna biru atau biru hijau menunjukan adanya steroid, sedangkan warna merah, merah muda atau ungu menunjukkan adanya triterpenoid (Harborne, 1984).

Pemeriksaan glikosida sebanyak 3 g serbuk simplisia ditimbang, disari dengan $30 \mathrm{ml}$ campuran dari 7 bagian etanol $95 \%$ dan 3 bagian air suling, ditambahkan dengan $1 \mathrm{ml}$ asam klorida $2 \mathrm{~N}$, direfluks selama 10 menit, dinginkan dan disaring. $20 \mathrm{ml}$ filtrat ditambahkan $25 \mathrm{ml}$ air suling dan $25 \mathrm{ml}$ timbal (II) asetat $0,4 \mathrm{M}$, dikocok dan didiamkam selama 5 menit, lalu disaring. Filtrat diekstraksi 3 kali, tiap kali dengan 20 ml campuran 3 bagian kloroform dan 2 bagian isopropanol, kemudian akan diperoleh dua lapisan (sari air dan sari pelarut organik). Kumpulan sari pelarut organik ditambahkan natrium sulfat anhidrat, lalu diuapkan di atas penangas air, kemudian dilarutkan sisa penguapan dengan 5 tetes asam asetat anhidrat dan 10 tetes asam sulfat pekat, jika terjadi warna biru atau hijau menunjukkan adanya glikosida. Kumpulan sari air dimasukkan dalam tabung reaksi diuapkan di atas penangas air, sisanya ditambahkan $2 \mathrm{ml}$ air dan 5 tetes pereaksi molish kemudian ditambahkan hati-hati $2 \mathrm{ml}$ asam sulfat pekat melalui dinding tabung, jika terbentuk cincin ungu pada batas kedua cairan menunjukkan adanya ikatan gula (Depkes RI, 1995).

Pembuatan Ekstrak serbuk simplisia diekstraksi dengan cara maserasi dengan menggunakan pelarut etanol $70 \%$.

Menurut Farmakope Indonesia Edisi III (1979), caranya adalah sebagai berikut: sebanyak $1600 \mathrm{~g}$ serbuk simplisia dimasukkan ke dalam sebuah bejana, dituangi dengan 75 bagian etanol (12 liter), ditutup, dibiarkan selama 5 hari terlindung dari cahaya sambil sering diaduk, diserkai, diperas. Ampas diremaserasi dengan 4 liter etanol hingga diperoleh 100 bagian. Dipindahkan ke dalam bejana tertutup, dibiarkan di tempat sejuk terlindung dari cahaya selama 2 hari. Dienap tuangkan atau disaring. Pemekatan ekstrak dilakukan dengan alat rotary evaporator pada suhu $40^{\circ} \mathrm{C}$, selanjutnya diuapkan di waterbath pada suhu $70-75^{\circ} \mathrm{C}$ sampai diperoleh ekstrak kental.

Pembuatan Larutan Uji Dengan Berbagai Konsentrasi, ekstrak etanol daun yen thuo dimasukkan kedalam flakon kemudian dilarutkan dengan pelarut DMSO hingga $1 \mathrm{ml}$. Larutan uji dibuat dengan konsentrasi $300 \mathrm{mg} / \mathrm{ml}, 200$ $\mathrm{mg} / \mathrm{ml}, 100 \mathrm{mg} / \mathrm{ml}, 50 \mathrm{mg} / \mathrm{ml}$. Masing-masing dimasukkan ke dalam flakon dan diberi label.

\section{Pembuatan Media Nutrient Agar}

Komposisi:

$\begin{array}{ll}\text { Lab-Lemco powder } & 1,0 \mathrm{~g} \\ \text { Yeast exstract } & 2,0 \mathrm{~g} \\ \text { Peptone } & 5,0 \mathrm{~g} \\ \text { Sodium chloride } & 5,0 \mathrm{~g} \\ \text { Agar } & 15,0 \mathrm{~g}\end{array}$

Cara pembuatan: Sebanyak 28 g nutrient agar ditimbang, dilarutkan kedalam air suling steril sebanyak $1000 \mathrm{ml}$. Lalu dipanaskan sampai bahan larut sempurna. Dalam keadaan panas larutan tersebut kemudian dimasukkan ke dalam erlenmeyer lalu disterilkan didalam autoklaf pada suhu $121^{\circ} \mathrm{C}$ selama 15 menit (Oxoid, 2013).

\section{Pembuatan Mueller-Hinton Agar}

Komposisi:

$\begin{array}{ll}\text { Beef infusion solids } & 2 \mathrm{~g} \\ \text { Acid hydrolysed casein } & 17,5 \mathrm{~g} \\ \text { Starch } & 1,5 \mathrm{~g} \\ \text { Agar } & 17 \mathrm{~g}\end{array}$

Cara pembuatan: Sebanyak 38 g MHA ditimbang, dilarutkan kedalam air suling steril sebanyak $1000 \mathrm{ml}$. Lalu dipanaskan sampai bahan larut sempurna kemudian dimasukkan kedalam erlenmeyer dan disterilkan didalam autoklaf pada suhu $121^{\circ} \mathrm{C}$ selama 15 menit (Oxoid, 2013).

\section{Pembuatan Agar Miring}

Sebanyak $3 \mathrm{ml}$ media nutrien agar cair dimasukkan kedalam tabung reaksi, diletakkan pada sudut kemiringan $30^{\circ}-45^{\circ}$ dan dibiarkan memadat. Kemudian disimpan dilemari pendingin (Lay, 1994). 


\section{Pembiakan Bakteri Pembuatan Stok Kultur Bakteri}

Satu koloni bakteri diambil dengan menggunakan jarum ose steril. Koloni bakteri tersebut kemudian ditanamkan pada media nutrient agar miring dengan cara menggores, setelah itu diinkubasi pada suhu $35-37^{\circ} \mathrm{C}$ selama 18- 24 jam.

\section{Penyiapan Inokulum Bakteri}

Koloni bakteri diambil dari stok kultur bakteri yang telah tumbuh pada media nutrient agar miring. Diambil dengan menggunakan jarum ose steril. Koloni bakteri tersebut kemudian disuspensikan kedalam tabung yang berisi $10 \mathrm{ml}$ larutan $\mathrm{NaCl} 0,9 \%$.

\section{Uji Aktivitas Antibakteri}

Sebanyak 0,1 ml inokulum dimasukkan ke dalam cawan petri steril, setelah itu dituang media MHA sebanyak $15 \mathrm{ml}$ dengan suhu $45^{\circ}-50^{\circ} \mathrm{C}$. Cawan petri digoyang seperti membentuk angka delapan secara perlahan diatas permukaan meja datar agar media dan suspensi bakteri tercampur rata dan dibiarkan memadat. Dilakukan pengujian aktivitas antibakteri dengan metode difusi cakram kertas yaitu dengan meletakkan cakram kertas yang telah direndam dalam beberapa konsentrasi larutan uji ekstrak etanol diatas media padat yang telah diinokulasi bakteri dan dibiarkan selama 15 menit, kemudian diinkubasi dalam inkubator pada suhu $36 \pm 1^{\circ} \mathrm{C}$ selama 18- 24 jam, setelah itu diukur diameter daerah hambatan (zona jernih) pertumbuhan disekitar cakram dengan menggunakan jangka sorong.

\section{Pembuatan Sediaan Krim Formulasi Dasar Krim}

Sediaan krim yang digunakan adalah krim dengan tipe minyak dalam air sebanyak $100 \mathrm{~g}$, dengan menggunakan formula standar sebagai berikut (Depkes RI, 1966):

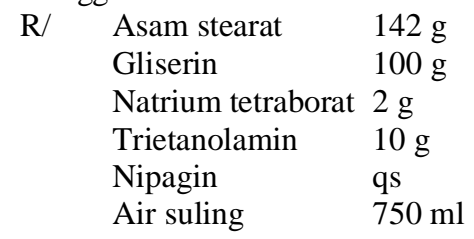

Formula dasar krim yang digunakan dimodifikasi dengan penggantian natrium tetraborat dengan cera alba. Hal ini dilakukan karena natrium tetraborat termasuk zat kimia yang dilarang penggunaannya didalam sediaan kosmetik dan jumlah gliserin yang digunakan dikurangi dengan tujuan menjaga konsistensi. Untuk itu formula dasar krim yang digunakan adalah:

\begin{tabular}{|c|c|}
\hline $\mathrm{R} /$ & Asam stearat \\
\hline & Cera alba \\
\hline & Paraffin liquid \\
\hline & Gliserin \\
\hline & Trietanolamin \\
\hline & Nipagin \\
\hline & Air suling ad \\
\hline
\end{tabular}

Cara pembuatan dasar krim: Asam stearat, cera alba, paraffin liquid dan gliserin dimasukkan ke dalam cawan penguap dan dilebur di atas penangas air (massa I). Air suling dimasukkan ke dalam beaker glass dan dipanaskan di atas penangas air lalu dimasukkan nipagin dan trietanolamin (massa II). Ditambahkan massa II ke dalam massa I di dalam lumpang panas sambil digerus secara terus menerus hingga terbentuk dasar krim.

\section{Formulasi Sediaan Krim}

Formulasi sediaan krim yang digunakan dalam penelitian ini yaitu ekstrak etanol daun yen thuo dan sediaan dasar krim. Sebanyak 2,5 gram ekstrak etanol daun yen thuo digerus di dalam lumpang yang bersih dan kering, ditambahkan sedikit demi sedikit sediaan dasar krim sambil digerus hingga homogen, dan dimasukkan ke dalam wadah dan disimpan ditempat yang kering pada suhu ruangan. Kemudian dilakukan evaluasi terhadap sediaan mengenai homogenitas, stabilitas dan pengukuran $\mathrm{pH}$ sediaan krim. 


\section{Pemeriksaan Homogenitas}

Sejumlah tertentu sediaan jika dioleskan pada sekeping kaca atau bahan transparan lain yang cocok, sediaan harus menunjukkan susunan yang homogen dan tidak terlihat adanya butiran kasar (Ditjen POM, 1979).

\section{Pemeriksaan Stabilitas Sediaan}

Pemeriksaan stabilitas sediaan meliputi bentuk, warna dan bau yang diamati secara visual (Ditjen POM, 1995). Sediaan dinyatakan stabil apabila warna, bau, dan penampilan tidak berubah secara visual selama penyimpanan, dan juga secara visual tidak ditumbuhi jamur.

\section{Pengukuran pH Sediaan}

Pengukuran $\mathrm{pH}$ sediaan dilakukan dengan menggunakan $\mathrm{pH}$ meter. Alat terlebih dahulu dikalibrasi dengan menggunakan larutan dapar standar netral $(\mathrm{pH} 7,0)$ dan larutan dapar $\mathrm{pH}$ asam $(\mathrm{pH} 4,0)$ hingga alat menunjukkan harga $\mathrm{pH}$ tersebut. Elektroda dicuci dengan air suling, lalu dikeringkan dengan tissue. Sampel dibuat dalam konsentrasi $1 \%$ yaitu ditimbang 1 gram sediaan dan dilarutkan dalam $100 \mathrm{ml}$ air suling. Kemudiaan elektroda dicelupkan dalam larutan tersebut. Dibiarkan alat menunjukkan harga pH sampai konstan. Angka yang ditunjukkan pH meter merupakan pH sediaan (Rawlins, 1977).

\section{HASIL DAN PEMBAHASAN}

Hasil pemeriksaan makroskopik yang dilakukan dengan cara organoleptis yaitu simplisia daun yen thuo berwarna hijau tua, berbentuk lonjong, urat daun yang jelas, permukaan daun berkilat, tepi daun bergerigi, dan ujung daun meruncing. Hasil pemeriksaan makroskopik serbuk simplisia daun yen thuo yang dilakukan dengan cara organoleptis yaitu serbuk berwarna hijau pudar, berasa agak pahit, dan bau khas. Penentuan golongan senyawa kimia simplisia ekstrak etanol daun yen thuo untuk mendapatkan informasi golongan senyawa metabolit sekunder yang ada didalamnya.

Tabel 1. Hasil skrining fitokimia serbuk simplisia daun yen thuo

\begin{tabular}{|c|c|c|}
\hline No. & Parameter & Serbuk simplisia \\
\hline 1. & Alkaloida & + \\
\hline 2. & Flavonoida & + \\
\hline 3. & Tanin & + \\
\hline 4. & Saponin & + \\
\hline 5. & Steroid/ triterpenoid & + \\
\hline 6. & Glikosida & + \\
\hline
\end{tabular}

Keterangan:

$(+)$ : mengandung golongan senyawa

$(-)$ : tidak mengandung golongan senyawa

Hasil skrining fitokimia serbuk simplisia memberikan hasil yang positif terhadap senyawa alkaloid, flavonoid, glikosida, saponin, tanin dan steroid/triterpenoid.

Golongan alkaloid teridentifikasi pada serbuk simplisia ditandai dengan adanya endapan putih atau putih kekuningan setelah ditambahkan pereaksi Mayer, endapan cokelat-hitam setelah ditambahkan pereaksi Bouchardat dan endapan merah/ jingga setelah ditambahkan pereaksi Dragendroff (Depkes RI, 1995). Golongan flavonoid memberikan hasil yang positif ditandai dengan penambahan serbuk $\mathrm{Mg}$ dengan $\mathrm{HCl}$ pekat terjadi warna kuning atau jingga. Uji identifikasi tanin menunjukkan hasil positif dengan penambahan pereaksi $\mathrm{FeCl} 3$ $1 \%$ terjadi warna biru kehitaman (Farnsworth, 1966). Pada uji identifikasi saponin memberikan hasil positif dengan terbentuknya busa setelah dikocok kuat-kuat selama 10 menit dan dengan penambahan 1 tetes $\mathrm{HCl} 2 \mathrm{~N}$ buih/ busa tidak hilang (Depkes RI, 1995). Steroid/triterpenoid memberikan hasil positif dengan terbentuknya warna biru hijau setelah ditambahkan pereaksi Liebermann- Burchard (Harborne, 1984). Adanya glikosida ditandai terbentuknya cincin ungu dengan pereaksi Molish. 
Hasil ekstraksi $250 \mathrm{~g}$ serbuk simplisia dengan cara maserasi menggunakan pelarut etanol 70\%, bertujuan untuk mengekstraksi senyawa yang terdapat pada simplisia daun yen thuo, baik bersifat polar maupun non polar, diperoleh ekstrak etanol daun yen thuo sebanyak 33,5 $\mathrm{g}$ (Rendemen $=0,134 \%)$.

Tabel 2. Hasil pengukuran diameter rata-rata daerah hambatan pertumbuhan bakteri Staphylococcus epidermidis

\begin{tabular}{|c|c|c|}
\hline No. & Konsentrasi $(\mathrm{mg} / \mathrm{ml})$ & Diameter daerah hambatan $(\mathrm{mm})^{*}$ \\
\hline 1. & 300 & 20,66 \\
\hline 2. & 200 & 18 \\
\hline 3. & 100 & 15,33 \\
\hline 4. & 50 & 12,33 \\
\hline 5. & Blanko (DMSO) & - \\
\hline \multicolumn{2}{|c|}{ Keterangan: } \\
\hline
\end{tabular}

(-) : Tidak ada hambatan

$(\mathrm{mm})$ :Diameter rata-rata tiga kali pengulangan

Hasil uji aktivitas antibakteri ekstrak etanol daun yen thuo dapat menghambat pertumbuhan bakteri Staphylococcus epidermidis. Sensitifitas bakteri patogen terhadap suatu antimikroba harus diuji dengan berbagai konsentrasi untuk menentukan tingkat konsentrasi yang menyebabkan pertumbuhan bakteri tersebut terhambat atau mati (Tim Mikrobiologi FK Brawijaya, 2003).

Pada Tabel terlihat bahwa konsentrasi dapat memenuhi persyaratan yang ditetapkan oleh Ditjen POM (1995) dengan batas daerah hambatan yang efektif lebih kurang 14-16 mm.

Berdasarkan hasil pengukuran diameter daerah hambatan memperlihatkan bahwa ekstrak etanol daun yen thuo memberikan aktivitas antibakteri yang efektif dalam menghambat pertumbuhan bakteri Staphylococcus epidermidis pada konsentrasi $100 \mathrm{mg} / \mathrm{ml}$ dengan diameter daerah hambat berturut-turut $14 \mathrm{~mm}, 16 \mathrm{~mm}, 16 \mathrm{~mm}$. Konsentrasi Hambat Minimum (KHM) diperoleh pada konsentrasi $50 \mathrm{mg} / \mathrm{ml}$ dengan diameter daerah hambat berturut-turut $12 \mathrm{~mm}, 13 \mathrm{~mm}, 12 \mathrm{~mm}$.

Data diatas menunjukkan bahwa ekstrak etanol daun yen thuo sesuai dengan batas daerah hambat yang dinilai efektif menurut Farmakope Indonesia, yaitu diameter daya hambat lebih kurang 14-16 mm.

Adanya aktivitas antibakteri dari ekstrak etanol daun yen thuo karena adanya kandungan senyawa metabolit sekunder yang bersifat sebagai antibakteri yaitu steroid/ triterpenoid, saponin, flavonoid dan tanin (Robinson, 1991). Mekanisme antibakteri flavonoid adalah membentuk senyawa kompleks dengan protein ekstraseluler dan terlarut sehingga dapat merusak membran sel bakteri dan diikuti dengan keluarnya senyawa intraseluler. Flavonoid juga berperan dalam menghambat metabolisme energi. Senyawa ini akan menganggu metabolisme energi dengan cara yang mirip dengan sistem respirasi, karena dibutuhkan energi yang cukup untuk penyerapan aktif berbagai metabolit dan untuk biosintesis makromolekul (Ngajow, et al., 2013). Tanin memiliki aktivitas antibakteri, toksisitas tanin dapat merusak membran sel bakteri (Akiyama et al., 2001). Mekanisme kerja tanin yaitu dapat melewati membran sel karena tanin dapat berpresipitasi pada pada protein (Abdollahzadeh et al., 2011). Tanin juga dapat membentuk ikatan hidrogen dengan protein di dinding sel bakteri, jika ikatan hidrogen terbentuk maka akan terjadi denaturasi protein yang menyebabkan metabolisme bakteri terganggu (Mailoa, et al., 2014). Mekanisme steroid sebagai antibakteri berhubungan dengan membran lipid dan sensitifitas terhadap komponen steroid yang menyebabkan kebocoran pada liposom. Mekansisme kerja saponin yaitu menyebabkan kebocoran pada protein dan enzim tertentu dari sel (Madduluri, et al., 2013). Saponin merupakan zat aktif permukaan yang dapat meningkatkan permeabilitas membran sehingga terjadi hemolisis sel, apabila saponin berinteraksi dengan kuman maka kuman tersebut akan pecah atau lisis (Poeloengan dan Pratiwi, 2010).

Hasil pemeriksaan homogenitas percobaan yang telah dilakukan pada sediaan krim tidak diperoleh butiran-butiran pada kaca objek maupun pada kertas perkamen dari sediaan dasar krim dan dari sediaan krim dengan ekstrak etanol daun yen thuo. Hasil uji stabilitas organoleptis sediaan krim ekstrak etanol daun yen thuo tidak mengalami perubahan warna, bau, dan bentuk. Sediaan krim ekstrak etanol daun yen thuo dinyatakan stabil selama penyimpanan 5 minggu. Sediaan dinyatakan stabil apabila tidak mengalami perubahan warna, bau dan bentuk (Draelos, 2006). 
Tabel 3. Data pemeriksaan stabilitas fisik sediaan krim secara organoleptis ekstrak etanol daun yen thuo

\begin{tabular}{|c|c|c|c|c|}
\hline \multirow{2}{*}{ enampilan } & \multicolumn{4}{|c|}{ Pengamatan (Minggu) } \\
\cline { 2 - 5 } & I & II & III & IV \\
\hline Warna & Hijau tua & Hijau tua & Hijau tua & Haua \\
\hline Bau & Spesifik daun yen thuo & Spesifik daun yen thuo & Spesifik daun yen thuo & Spesifik daun yen thuo \\
\hline Bentuk & Semi padat & Semi padat & Semi padat & Semi padat \\
\hline Warna & Hijau tua & Hijau tua & Hijau tua & Hijau tua \\
\hline
\end{tabular}

Hasil pengukuran $\mathrm{pH}$ dari sediaan krim ekstrak etanol daun yen thuo dengan pengamatan selama 5 minggu terlihat bahwa $\mathrm{pH}$ sediaan krim ekstrak etanol daun yen thuo tidak mengalami penurunan. $\mathrm{pH}$ sediaan ditentukan dengan menggunakan $\mathrm{pH}$ meter. Hasil pengujian terhadap $\mathrm{pH}$ sediaan krim yang diperoleh menunjukkan bahwa sediaan krim yang dihasilkan sesuai dengan $\mathrm{pH}$ kulit dan dapat digunakan dengan aman dan tidak menyebabkan iritasi pada kulit karena menurut Balsam dan Sagarin (1972), pH sediaan krim yang sesuai untuk pH kulit adalah antara 5 sampai 8.

Tabel 4. Data pengukuran $\mathrm{pH}$ sediaan krim ekstrak etanol daun yen thuo

\begin{tabular}{|c|c|c|c|c|c|c|}
\hline \multirow{2}{*}{ Formula } & \multicolumn{5}{|c|}{ Lama pengamatan (minggu) } \\
\cline { 2 - 7 } & 0 & I & II & III & IV & V \\
\hline Krim ekstrak etanol daun yen thou & 7 & 7 & 7 & 7 & 7 & 7 \\
\hline
\end{tabular}

\section{KESIMPULAN}

Hasil skrining serbuk simplisia daun yen thuo menunjukkan hasil positif terhadap alkaloid, flavonoid, tanin, saponin, steroid/triterpenoid dan glikosida.Hasil uji aktivitas antibakteri ekstrak etanol daun yen thuo memberikan aktivitas antibakteri yang efektif dalam menghambat pertumbuhan bakteri Staphylococcus epidermmidis pada konsentrasi $100 \mathrm{mg} / \mathrm{ml}, 200 \mathrm{mg} / \mathrm{ml}$, dan $300 \mathrm{mg} / \mathrm{ml}$.Formulasi krim ekstrak etanol daun yen thuo merupakan sediaan krim yang stabil dan homogen.

\section{DAFTAR PUSTAKA}

1. Anief.(2000). Farmasetika. Cetakan kedua. Yogyakarta: Gadjah mada university press. Hal.116-117

2. Ansel, Howard C. (1989). Pengantar bentuk sediaan farmasi. Edisi ke empat. Jakarta : Universitas Indonesia Press. Hal 513-115,607.

3. Boyd dan F. Robert. 1988. General Microbiology. Second Edition. Times Mirror/Mosby college publishing.

4. Ditjen POM. (1995). Farmakope Indonesia. Edisi keempat. Departemen kesehatan RI. Jakarta. Hal. 6, 896.

5. Ditjen POM.(1989). Materi Medika Indonesia. Jilid V. Jakarta : Departemen Kesehatan RI. Jakarta. Hal. 534-540.

6. Dwidjoseputro. (1988). Dasar-dasar mikrobiologi. Jakarta : Penerbit Djambatan. Hal 22, 118-134

7. Depkes RI. (2000). Parameter standar umum ekstrak tumbuhan obat. Jakarta : Departemen kesehatan RI. Hal. 1, 10-11

8. Ganiswara, S. (1995). Farmakologi dan terapi. Edisi 4. Jakarta : penerbit Universitas Indonesia. Hal :571573

9. Gunawan, D., dan S. Mulyani. 2004. Ilmu Obat Alam (Farmakognosi). Jilid 1.Penebar Swadaya. Jakarta

10. Graham, Robin-brown, Tony Burns.2002 Lecture Notes Dermatology edisi 8. Erlangga .jakarta

11. Irianto, K. (2006). Mikrobiologi menguak dunia mikroorganisme. Jilid satu. Bandung : Penerbit Yrama Widya. Hal 35

12. Jaffar, F.M., C.P. Osman, N.H . Ismail dan K. Awang . 2007. Anaysis of essential oil of leaves, stems, flowers dan rhizomes of Etlingera Elatior (JACK) R.M. SMITH. The malaysian journal of analytical sciences, Vol. 11: 269-273.

13. Jawetz, Melnick dan adelberg's. 2010 medical microbiology $26^{\text {th }}$ Edition. McGraw-Hill companies. USA

14. Jawetz, E., J.L. Melnick dan E. A. Adelberg's.1996. mikrobiologi kedokteran. Edisi-20. Alih Bahasa Edi Nugroho, R.F.Maulany. Jakarta. EGC

15. Jay, J. M. (1992). Modern Food Microbiology. 4th Ed. USA: Wayne State University. Page 186. 
16. Kusmiyati dan N.W.S. Agustini. 2006. Uji aktivitas senyawa antibakteri dari mikroalga porphyridium cruentum. Biodiversitas Vol. 8: 48-53.

17. Oxoid.(2013). Nutrient Agar and Nutrient Browth.England: Oxoid LTD.

18. Pelczar , J.M. dan E.C.S. Chan. 1998. Dasar-dasar mikrobiologi 2. Universitas Indonesia. Jakarta.

19. Pelczar, J.M., dan E.C.S.Chan. 2010. dasar-dasar mikrobiologi .universitas Indonesia. Jakarta

20. Pratiwi, S.T. (2008). Mikrobiologi Farmasi. Jakarta : Penerbit Erlangga. Hal 6, 22-24, 105-117

21. Rowe, R.C., Sheskey, P.J., and Owen, S.C. (2009).Handbook of PharmauceticalExcipiens.Pharmaceutical Press, American pharmaceutical Association.6th edition.Pages 283, 441, 697 and 754.

22. Sunanti. 2007. Aktivitas antibakteri Ekstrak Tunggal Bawang putih (allium sativa) dan rimpang kunyit (curcuma domestica) terhadap salmonella typhinaria. Skripsi :Departemen Biologi FMIPA. Institut Pertanian Bogor.

23. Syamsuhidayat.(2000). InventarisTanamanObat Indonesia.EdisiPertama. Jakarta: DepartemenKesehatan RI danKesejahteraanSosial. Halaman 134-140.

24. Syamsuni.(2006). IlmuResep. Jakarta: Penerbit Buku Kedokteran EGC. Halaman 133.

25. Tranggono, R.I.S dan Latifah, F. (2007). Buku Pegangan Ilmu Pengetahuan Kosmetik. Jakarta: GramediaPustakaUtama. Halaman 93-96.

26. Suryanto, D., dan Erman, M. (2006). Mikrobiologi. Medan :Departemen Biologi FMIPA Universitas Sumatera Utara. Hal 10-11

27. Volk, W.A. dan Wheeler, M.F. (1993).MikrobiologiDasar. Jilid I. Alih Bahasa: Markam. Jakarta: Erlangga. Halaman 33-40, 218-219, 266.

28. Wasitaatmadja, S.M. (1997). PenuntunIlmuKosmetikMedik. Jakarta: Penerbit UI-Press. Halaman 59 - 60. 